\title{
Follow-Up Results of Patients Treated with Surgical Clipping Following Aneurysmal Subarachnoid Hemorrhage
}

\section{Anevrizmal Subaraknoid Kanama Nedeniyle Ameliyat Edilen Hastaların Takip Sonuçları}

(D) Leyla Ramazanoğlu,' (1) Ali Fatih Ramazanoğlu, ${ }^{2}$ (1) Mehmet Reşit Önen ${ }^{3}$

${ }^{1}$ Department of Neurology Fatih Sultan Mehmet Training and Research Hospital,

Istanbul, Turkey

${ }^{2}$ Department of

Neurosurgery, Ümraniye

Training and Research Hospital, İstanbul, Turkey

${ }^{3}$ Department of Neurosurgery, Medicalpark Hospital, İstanbul, Turkey

Cite this article as: Ramazanoğlu L, Ramazanoğlu AF, Önen MR. Follow-Up Results of Patients Treated with Surgical Clipping Following Aneurysmal Subarachnoid Hemorrhage. Bosphorus Med J 2021;8(2):101-106.

Received: 21.12 .2020 Accepted: 08.03.2021

Correspondence: Dr. Leyla Ramazanoğlu. Fatih Sultan Mehmet Eğitim Ve Araştırma Hastanesi, Nöroloj Kliniği, İstanbul, Turkey Phone: +905323643161

e-mail: afleylaak@hotmail.com

\section{ABSTRACT}

Objectives: The aim of this study was to estimate the prognosis and mortality rates of patients 1 year after surgical clipping of aneurysmal subarachnoid hemorrhage.

Methods: This retrospective study included 75 patients treated with surgical clipping in multicenter neurosurgery clinics. Patients who were treated by endovascular coiling were not included in the study. Data related to the clinical status of the patients were obtained from the patient files. The Hunt-Hess, Fisher, and Glasgow Coma Scale (GCS) scales were evaluated, and the relationships between these scales and mortality.

Results: Evaluation was made of 75 patients comprising 41 (54.7\%) males and 34 (45.3\%) females with a mean age of $49.4 \pm 11.5$ years. The Glasgow Coma score was determined as median 14 (range, 3-15), the Fisher score as median 2 (range, 1-4), and the Hunt-Hess score as median 2 (range, 1-5). A significant relationship was determined between the Fisher scale and the mortality rate. The GCS and Hunt-Hess scales were not significant prognostic factors for mortality. No significant association was determined between age, gender, aneurysm location, and mortality.

Conclusion: The results of this study indicate a relationship between the Fisher scale and mortality.

Keywords: Aneurysm; subarachnoid hemorrhage; surgical clipping.

\section{ÖZET}

Amaç: Bu çalışmanın amacı anevrizmal subaraknoid kanamaların cerrahi kliplenmeden sonra bir yıllık prognozları ve mortalite oranlarını sunmaktır.

Yöntem: Retrospektif olarak iki ayrı beyin cerrahisi kliniğinde cerrahi olarak kliplenen 75 subaraknoid kanamalı anevrizma olgusu incelenmiştir. Endovasküler koil uygulanan olgular çalışmaya alınmamıştır. Hastaların klinik durumları HuntHess, Fisher ve GKS skalaları kullanılarak değerlendirilmiştir. Fonksiyonel durumları değerlendirmede modifiye Rankin Skalası (mRS) kullanılmıştır.

Bulgular: Değerlendirilen 75 hastanın 41 (\%54.7)'i erkek, 34 (\%45.3)'ü kadın, ortalama yaşları 49.4 11 1.5 idi. Glasgow koma skoru ortalama 14 (range: 3-15), Fischer skoru ortalama 2 (range: 1-4) ve HuntHess skoru ise ortalama 2 (range: 1-5) idi. Fischer skalası ile mortalite oranları arasında anlamlı ilişki saptandı. Ancak GKS ve HuntHess skorları ile prognostic faktörler arasında anlamlı ilişki görülmedi. Aynı şekilde yaş, cinsiyet ve anevrizma lokalizasyonlarınında mortalite ilişkisi görülmedi.

Sonuç: Bu çalışma Fischer skalası ile mortalite arasında ilişki olduğunu göstermiştir.

Anahtar sözcükler: Anevrizma; subaraknoid kanama; cerrahi klipleme.

A cute subarachnoid hemorrhage ( $\mathrm{SAH})$ is a serious condition that affects not only the brain but also other multiple organ systems ${ }^{[1]}$ and has been reported to be responsible for $6-8 \%$ of all strokes. ${ }^{[2,3]}$
The worldwide prevalence of SAH is approximately 3-23/100,000. ${ }^{[4,5]}$ The rupture of an intracranial aneurysm is the underlying cause in $85 \%$ of cases. ${ }^{[6]}$ Other causes of SAH include trauma, cerebral venous thrombosis, arteriove- 
nous malformations, dural arteriovenous fistulas, arterial dissection, mycotic aneurysms, pituitary apoplexy, hypertension, cocaine abuse, tobacco use, excessive alcohol, sympathomimetic drugs, and a family history of Ehler-Danlos or polycystic kidney disease. ${ }^{[6,7]}$

Neurological manifestations are severe, and following SAH, there can be seen to be a sudden onset of headache (described by patients as the worst ever experienced in their life), signs of meningeal irritation and increased intracranial pressure, a decline in consciousness even as far as coma, epileptic seizures, and focal neurological deficits. Multisystemic complications (ocular, cardiac, and pulmonary) and electrolyte imbalances are also seen following SAH. ${ }^{[1]}$ When SAH is suspected, non-contrast computed tomography (CT) should be performed. Some magnetic resonance 1maging (MRI) sequences (especially T2-weighted gradient and FLAIR) are more sensitive in the detection of SAH but availability and cooperation of the patient are poorer. If the CT or MRI scans are negative but the suspicion of SAH remains, the next step is lumbar puncture. The etiology of SAH is defined with CT, MRI, or conventional digital subtraction angiography (DSA). ${ }^{[8]}$ The Hunt and Hess Scale and WFNS scale show the severity of the clinical status. ${ }^{[8]}$ The Fisher Scale is used to understand the amount and extent of the hemorrhage. ${ }^{[8]}$ Complications include re-bleeding, acute and chronic hydrocephalus, acute ischemic lesions, vasospasm, and non-neurological complications such as electrocardiogram abnormalities, severe stress cardiomyopathy, acute pulmonary edema, and pupillary abnormalities. [9-11] Although the mortality rate has decreased in the past 10 years, ${ }^{[12]}$ it still remains as high as $50 \%$ in aneurysmal $\mathrm{SAH}^{[13]}$ and $25 \%$ of these patients are exitus before hospital admission. ${ }^{[14]}$ As a result of complications, the mortality rate in the first 3 months can reach 35\%. ${ }^{[15]}$ The morbidity rate is $15-20 \%$ for the same population and only $25-35 \%$ of the patients recover to a moderate-good degree. ${ }^{[16]}$ The treatment options are endovascular coiling and surgical clipping. ${ }^{[17]}$

The aim of this study was to investigate the mortality rate of patients throughout 1 year following SAH surgery in the period 2009-2012.

\section{Methods}

This retrospective study included 75 patients treated with surgical clipping in multicenter neurosurgery clinics. Local ethical committee approval was obtained. Data related to the clinical status of the patients were obtained from the pa- tient files. The Hunt-Hess, Fisher, and Glasgow Coma Scale (GCS) scales were evaluated, and the relationships between these scales and mortality.

Patients were excluded from the study if they were admitted with SAH but died before the clipping procedure, if DSA was negative, or if treatment was applied with endovascular methods.

A record was made of the demographic, clinical, and radiological data of each patient. Neurological clinical signs were evaluated according to the Hunt and Hess classification. The GCS was used to assess the level of consciousness, and the Fisher grading scale for the hemorrhage status on CT. Radiological signs, CT, and DSA results were recorded on the form. At 1 year postoperatively, the patients were contacted by telephone and invite to the hospital for evaluation. Bedridden patients were visited in their homes, and deaths were recorded according to the official notifications. Modified Rankin Scale (mRS) score was used to determine the functional outcome. mRS 0-1 score was accepted as excellent prognosis and $\mathrm{mRS}$ 2-6 was accepted to moderate-to severe disability and death.

\section{Statistical Analysis}

Data obtained in the study were analyzed statistically using Number Cruncher Statistical System 2007 and Power Analysis and Sample Size 2008 Statistical Software (Utah, USA). Descriptive statistics were stated as mean \pm standard deviation, median, minimum and maximum values, number (n), and percentage (\%). In the comparisons of quantitative data and parameters not showing normal distribution, the Mann-Whitney U-test was applied. Fisher's exact test and Yates Continuity Correction test (Yates corrected Chi-square) were used in the comparison of qualitative data. The level of statistical significance was set at $\mathrm{p}<0.01$ and $\mathrm{p}<0.05$ levels. Ethics committee approval date and number: 17/09/2020, B.10.1.TKH.4.34.H.GP.0.01/310.

\section{Results}

Evaluation was made of a total of 75 patients comprising 41 (54.7\%) males and 34 (45.3\%) females with a mean age of $49.4 \pm 11.5$ years (Table 1 ).

The Glasgow Coma score was determined as mean 13.4 \pm 2.4 (median 14 and range, 3-15). The Fisher score was determined as mean $2.4 \pm 1.0$ (median 2 and range, 1-4), with Fisher score of one determined in $13(17.3 \%)$ patients, two in in 34 (45.4\%), three in $12(16.0 \%)$, and four in $16(21.3 \%)$. 
Table 1. Age, gender, and aneurysm localizations distribution of patients

\begin{tabular}{lcc} 
& Min-Max & Avg \pm SD \\
\hline Age (years) & $14-77$ & $49.48 \pm 11.58$ \\
& $\mathbf{n}$ & $\%$ \\
\hline Gender & & \\
Male & 41 & 54.7 \\
Female & 34 & 45.3 \\
Aneurysm localization 1 $(\mathrm{n}=75)$ & & \\
ACA & 8 & 10.7 \\
ACom & 29 & 38.7 \\
ICA & 6 & 8.0 \\
MCA & 25 & 33.3 \\
PCom & 7 & 9.3 \\
Aneurysm Localization 2 $(\mathrm{n}=10)$ & & \\
ACom & 1 & 10.0 \\
MCA & 6 & 60.0 \\
PCom & 2 & 20.0 \\
ICA, Pcom & 1 & 10.0
\end{tabular}

The Hunt and Hess score was determined as mean 2.1 \pm 1.1 (median 2.37 and range, 1-5), with a score of 1 determined in $28(37.4 \%)$ patients, two in 21 (28.0\%), three in $16(21.3 \%)$, four in $9(12.0 \%)$, and five in $1(1.3 \%)$ (Table 2).

Table 2. GCS, Fisher, and Hunt and Hess scale points of all 75 patients

\begin{tabular}{lcc} 
& Min-Max & $\begin{array}{c}\text { Avg } \pm \text { SD } \\
\text { (Median) }\end{array}$ \\
\hline GCS & $3-15$ & $13.36 \pm 2.39(14)$ \\
Fisher & $1-4$ & $2.41 \pm 1.01(2)$ \\
HUNT and HESS & $1-5$ & $2.12 \pm 1.09(2)$ \\
& $\mathbf{n}$ & $\%$ \\
\hline Fisher & & \\
1 & 13 & 17.3 \\
2 & 34 & 45.4 \\
3 & 12 & 16.0 \\
4 & 16 & 21.3 \\
HUNT and HESS & & \\
1 & 28 & 37.4 \\
2 & 21 & 28.0 \\
3 & 16 & 21.3 \\
4 & 9 & 12.0 \\
5 & 1 & 1.3 \\
\hline
\end{tabular}

GCS: Glasgow Coma Scale.
When aneurysm localization was evaluated, ACA was determined in $10.7 \%(\mathrm{n}=8)$, Acom in $38.7 \%(\mathrm{n}=29)$, ICA in $8.0 \%$ $(\mathrm{n}=6)$, MCA in 33.3\% $(\mathrm{n}=25)$, and Pcom in 9.3\% $(\mathrm{n}=7)$. In ten patients with multiple aneurysms, localization was determined as 10.0\% ( $n=1)$ Acom, 60.0\% ( $n=6)$ MCA, 20.0\% ( $n=2)$ Pcom, and 10.0\% (n=1) ICA and Pcom (Table 1).

Neurological status after 1 year was $72.0 \%(n=54)$ mRS 0-1 accepted as excellent prognosis versus $28.0 \% \mathrm{mRS} 2-6$ (Table 3). A significant correlation was determined between Fisher scale and mortality. A significant relationship was determined between age, gender, Hunt and Hess scale, GCS scale, and the localization of aneurysm and mortality. Evaluations were not made of the size of the aneurysm and mortality. The Hunt and Hess scores were seen to be higher and the GCS scores lower in the non-survivors group, but not to a statistically significant level (Tables 4-6).

\section{Discussion}

Endovascular coiling and surgical clipping are treatment modalities for aneurysmal SAHs. Patients with advanced age, poor clinical status, underlying multiple systemic conditions, and top of the basilar artery localization and at high risk for surgery are candidates for endovascular coiling. Surgical clipping is the first-line option for patients with

\begin{tabular}{ccc} 
Table 3. Prognosis after 1 year & & \\
& Patient number & $\%$ \\
\hline Survey after 1 year & & \\
mRS $(0-1)$ & 54 & 72.0 \\
mRS $(2-6)$ & 21 & 28.0 \\
\hline
\end{tabular}

mRS: Modified Rankin Scale.

Table 4. Age and gender distribution of patients according to mortality

\begin{tabular}{cccc} 
& \multicolumn{2}{c}{ Mortality } & P \\
\cline { 2 - 3 } & No (n=68) & Yes (n=7) & \\
\hline Age (years) & $48.81 \pm 11.60(48)$ & $56.00 \pm 9.87(61)$ & ${ }^{a} 0.109$ \\
& $\mathbf{n}(\%)$ & $\mathbf{n}(\%)$ & \\
\hline Gender & & & b 0.695 \\
Male & $38(55.9)$ & $3(42.9)$ & \\
Female & $30(44.1)$ & $4(57.1)$ & \\
\hline
\end{tabular}

aMann Whitney U test; bYates continuity correction. 
Table 5. The evaluation of Fisher, HUNT and HESS, and GCS scores according to mortality

\begin{tabular}{|c|c|c|}
\hline \multicolumn{2}{|c|}{ Mortality } & I \\
\hline No $(n=68)$ & Yes $(n=7)$ & \\
\hline n (\%) & n (\%) & \\
\hline
\end{tabular}

\begin{tabular}{lccc} 
Fisher & & & \\
1 & $13(19.1)$ & $0(0)$ & \\
2 & $32(47.1)$ & $2(28.6)$ & \\
3 & $10(14.7)$ & $2(28.6)$ & \\
4 & $13(19.1)$ & $3(42.9)$ & \\
Min-Max (Median) & $1-4(2)$ & $2-4(3)$ & $0.043^{*}$ \\
mean \pm SD & $2.34 \pm 1.00$ & $3.14 \pm 0.90$ & \\
HUNT and HESS & & & \\
1 & $27(39.7)$ & $1(14.3)$ & \\
2 & $19(27.9)$ & $2(28.6)$ & \\
3 & $15(22.1)$ & $1(14.3)$ & \\
4 & $6(8.8)$ & $3(42.9)$ & \\
5 & $1(1.5)$ & $0(0)$ & \\
Min-Max (Median) & $1-5(2)$ & $1-4(3)$ & 0.073 \\
Mean $\pm S D$ & $2.04 \pm 1.06$ & $2.86 \pm 1.21$ & \\
GKS & & & \\
Min-Max (Median) & $3-15(14)$ & $7-15(12)$ & 0.067 \\
Mean $\pm S D$ & $13.56 \pm 2.21$ & $11.43 \pm 3.36$ & \\
\hline
\end{tabular}

Mann-Whitney U-test *p<0.05; GCS: Glasgow Coma Scale.

Table 6. Evaluation of mortality according to aneurysm location

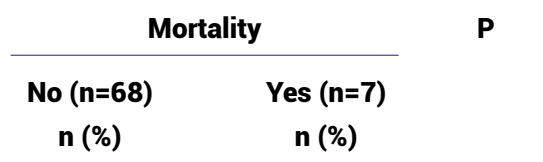

\begin{tabular}{lccc}
\hline Aneurysm location & & & \\
ACA & $8(11.8)$ & $0(0)$ & 1.000 \\
Acom & $24(35.3)$ & $5(71.4)$ & 0.101 \\
ICA & $6(8.8)$ & $0(0)$ & 1.000 \\
MCA & $24(35.3)$ & $1(14.3)$ & 0.413 \\
Pcom & $6(8.8)$ & $1(14.3)$ & 0.512 \\
\hline
\end{tabular}

Fisher's exact test.

an aneurysm with a wide neck to body ratio, middle cerebral artery aneurysm, aneurysm with large parenchymal hematoma, and arterial branches arising from the dome or body of aneurysm. ${ }^{[17]}$ All the patients included in this study underwent surgical clipping of the aneurysms. A mortality rate of $>30 \%$ has been reported in aneurysmal SAH. ${ }^{[1]}$ Figueredo et al. ${ }^{[18]}$ reported the mortality rate to be $11.2 \%$ in their study. In the current study, the mortality rate was 9\%.
The incidence of $\mathrm{SAH}$ is $50 \%$ higher in females than in males and females have a higher rate of vasospasms. Furthermore, in the $6^{\text {th }}$ decade of life, women have a higher incidence of rupture associated with hormonal changes related to perimenopause. ${ }^{[18,19]}$ Niskaren et al. ${ }^{[20]}$ and Sandvei et al. ${ }^{[21]}$ found no gender difference in the 1-year and 6-month outcomes of early aneurysmal surgery. According to other studies, male gender is related to higher mortality rates. ${ }^{\text {[22-24] }}$ In the current study, no significant relationship was determined between mortality and gender.

Older age has been associated with an increased mortality rate after aneurysmal SAH. ${ }^{[25]}$ In the current study, no statistically significant relationship was determined between mortality and age.

Mortality has been seen to increase with high Fisher scores. In a study of 26 patients, Figueredo reported that a Fisher scale score of 4 had a mortality rate of 2.55. ${ }^{[18]}$ Choita et al. ${ }^{[22]}$ also showed an association between high Fisher scores and poor prognosis. In contrast, Orakdogen et al. ${ }^{[26]}$ showed no prognostic value of the Fisher score in their study. In the current study, it was postulated that there could be a relationship between the Fisher score and mortality. SAH with parenchymal and/or intraventricular hematoma has a poor prognostic outcome. It was hypothesized that this could be related to the increased risk of complications of vasospasm and hydrocephalus. ${ }^{[27,28]}$

Mortality rates are expected to be higher with high Hunt and Hess scores and lower GCS. ${ }^{[18,29,30]}$ Lantigua also reported the identification of new temporal trends showing lower mortality in Hunt and Hess Grades 4 and 5. ${ }^{[30]}$ Hoogmoed et al. ${ }^{[31]}$ stated that the neurological condition may still be dominated by the event of the initial ictus, seizures, or acute hydrocephalus rather than neurological status on admission. This might explain why the initial neurological condition does not discriminate well for a good clinical outcome. In a study by Choita et al., ${ }^{[22]}$ a significant improvement in the GCS score was shown. In the current study, no significant relationship was determined between the GCS, and Hunt and Hess scores and mortality. This reflects the power of recovery at a younger age. Ogilvy also stated that in the between-group differences of individual grades, mortality was not significantly different for Hunt and Hess Grades 0-3, but Hunt and Hess Grade 5 was excluded from those studies. ${ }^{[29,32]}$

Choita et al. ${ }^{[22]}$ observed no association between the localization of the aneurysm and prognosis. Kassel et al. ${ }^{[33]}$ sug- 
gested that aneurysms in the vertebrobasilar system have poor prognosis. Orakdogen et al. ${ }^{[26]}$ reported that in distally located aneurysms, the rates of MCA and ACA were significantly higher among the non-survivors. Ogilvy et al. ${ }^{[29]} \mathrm{did}$ not find any significant difference in outcomes when anterior versus posterior locations were compared. In the current study, no significant relationship was detected between aneurysm localization and prognosis. The size of the aneurysm could be a significant prognostic factor but this was not evaluated in this study. ${ }^{[26,29]}$

In a multicenter study of 2922 patients, the mortality rate was reported as $14 \%$, and the discharge rate with a good prognosis as $69 \% .{ }^{[33]}$ In addition to these data, Osawa et al. ${ }^{[34]}$ reported a $12.9 \%$ mortality rate and $68.5 \%$ rate of discharge with a good neurological status in a study of 2055 cases. In the present study, $72.0 \%$ of the patients resumed as excellent prognosis (mRS $0-1$ ) and $28.0 \%$ of patients were mRS 2-6 as moderate-to severe disability and among them seven patients were died as mRS score 6 . To date, there has been no long-term study of mortality in SAH in Turkey. There are a few studies related to hospital data only, in which only the mortality rates have been reported with no examination of the reasons for mortality. ${ }^{[35,36]}$

\section{Conclusion}

Although new interventions are applying in SAH treatment, SAH is still remaining a serious disorder and can cause morbidity and mortality. The findings of this study indicate that the Fisher scale is a significant predictor of outcome and mortality after SAH.

\section{Disclosures}

Ethics Committee Approval: Ümraniye Training and Research Hospital Clinical Ethics Committee (No: B.10.1.TKH.4.34.H.GP.0.01/310 - 17.09.2020).

Peer-review: Externally peer-reviewed.

Conflict of Interest: None declared.

Authorship Contributions: Concept - L.R., A.F.R., M.R.Ö.; Design - L.R., A.F.R., M.R.Ö.; Supervision - L.R., A.F.R., M.R.Ö.; Materials - L.R., A.F.R., M.R.Ö.; Data collection \&/or processing L.R., A.F.R., M.R.Ö.; Analysis and/or interpretation - L.R., A.F.R., M.R.Ö.; Literature search - L.R., A.F.R., M.R.Ö.; Writing - L.R., A.F.R., M.R.Ö.; Critical review - L.R., A.F.R., M.R.Ö.

\section{References}

1. Petridis AK, Kamp MA, Cornelius JF, Beez T, Beseoglu K, Turowski B, et al. Aneurysmal Subarachnoid Hemorrhage.
Dtsch Arztebl Int 2017;114:226-36.

2. Özdemir M, Bozkurt M. Subarachnoid hemorrhage and treatment of complications. J Ankara Univ Facult Med 2011;64.

3. Biller J, Godersky JC, Adams HP Jr. Management of aneurysmal subarachnoid hemorrhage. Stroke 1988;19:1300-5.

4. Peerless SJ, Hernesniemi JA, Drake CG. Posterior circulation aneurysms. In: Wilkins RH, Rengachary SS, editors. Neurosurgery. Vol. 2. New York: McGraw Hill; 1996. p. 2331-56.

5. Stegmayr B, Eriksson M, Asplund K. Declining mortality from subarachnoid hemorrhage: Changes in incidence and case fatality from 1985 through 2000. Stroke 2004;35:2059-63.

6. Macdonald RL, Schweizer TA. Spontaneous subarachnoid haemorrhage. Lancet 2017;389:655-66.

7. Marcolini E, Hine J. Approach to the diagnosis and management of subarachnoid hemorrhage. West J Emerg Med 2019;20:20311.

8. Vivancos J, Gilo F, Frutos R, Maestre J, García-Pastor A, Quintana $\mathrm{F}$, et al. Clinical management guidelines for subarachnoid haemorrhage. Diagnosis and treatment. Neurologia 2014;29:353-70.

9. Koza Y, Aydin N, Aydin MD, Koza EA, Bayram E, Atalay C, et al. Neurogenic stress cardiomyopathy following subarachnoid hemorrhage is associated with vagal complex degeneration: First experimental study. World Neurosurg 2019;129:e741-8.

10. Onen MR, Yilmaz I, Ramazanoglu L, Tanriverdi O, Aydin MD, Kanat A, et al. Rational roots of sympathetic overactivity by neurogenic pulmonary edema modeling arising from sympathyco-vagal imbalance in subarachnoid hemorrhage: An experimental study. World Neurosurg 2016;92:463-70.

11. Onen MR, Yilmaz I, Ramazanoglu L, Aydin MD, Keles S, Baykal $\mathrm{O}$, et al. Uncovering the forgotten effect of superior cervical ganglia on pupil diameter in subarachnoid hemorrhage: An experimental study. Turk Neurosurg 2018;28:48-55.

12. Special report from the National Institute of Neurological Disorders and Stroke. Classification of cerebrovascular diseases III. Stroke 1990;21:637-76.

13. Fogelholm R. Subarachnoid hemorrhage in middle-Finland: Íncidence, early prognosis and indications for neurosurgical treatment. Stroke 1981;12:296-301.

14. Hop JW, Rinkel GJ, Algra A, van Gijn J. Case-fatality rates and functional outcome after subarachnoid hemorrhage: A systematic review. Stroke 1997;28:660-4.

15. Chehrazi BB, Giri S, Joy RM. Prostaglandins and vasoactive amines in cerebral vasospasm after aneurysmal subarachnoid hemorrhage. Stroke 1989;20:217-24.

16. Säveland H, Sonesson B, Ljunggren B, Brandt L, Uski T, Zygmunt $\mathrm{S}$, et al. Outcome evaluation following subarachnoid hemorrhage. J Neurosurg 1986;64:191-6.

17. Suarez JI. Diagnosis and management of subarachnoid hemorrhage. Continuum (Minneap Minn) 2015;21:1263-87.

18. Figueredo LF, Pedraza-Ciro MC, Lopez-McCormick JS, Rueda-Esteban RJ, Mejía-Cordovez JA. Aneurysmal subarachnoid hemorrhage associated with small aneurysms in smokers and women: A retrospective analysis. World Neurosurg X 2019;4:100038.

19. De Marchis GM, Schaad C, Fung C, Beck J, Gralla J, Takala J, et al. Gender-related differences in aneurysmal subarachnoid hemorrhage: A hospital based study. Clin Neurol Neurosurg 
2017;157:82-7.

20. Niskanen MM, Hernesniemi JA, Vapalahti MP, Kari A. One-year outcome in early aneurysm surgery: Prediction of outcome. Acta Neurochir (Wien) 1993;123:25-32.

21. Sandvei MS, Mathiesen EB, Vatten LJ, Müller TB, Lindekleiv H, Ingebrigtsen $\mathrm{T}$, et al. Incidence and mortality of aneurysmal subarachnoid hemorrhage in two Norwegian cohorts, 19842007. Neurology 2011;77:1833-9.

22. Chotai S, Ahn SY, Moon HJ, Kim JH, Chung HS, Chung YG, et al. Prediction of outcomes in young adults with aneurysmal subarachnoid hemorrhage. Neurol Med Chir (Tokyo) 2013;53:15762.

23. Pakarinen S. Incidence, aetiology, and prognosis of primary subarachnoid haemorrhage. A study based on 589 cases diagnosed in a defined urban population during a defined period. Acta Neurol Scand 1967;43 Suppl 29:1-28.

24. Jehle D, Moscati R, Frye J, Reich N. The incidence of spontaneous subarachnoid hemorrhage with change in barometric pressure. Am J Emerg Med 1994;12:90-1.

25. Goldberg J, Schoeni D, Mordasini P, Z’Graggen W, Gralla J, Raabe A, et al. Survival and outcome after poor-grade aneurysmal subarachnoid hemorrhage in elderly patients. Stroke 2018;49:2883-9.

26. Orakdogen M, Emon ST, Somay H, Engin T, Ates O, Berkman MZ. Prognostic factors in patients who underwent aneurysmal clipping due to spontaneous subarachnoid hemorrhage. Turk Neurosurg 2016;26:840-8.

27. Chen S, Luo J, Reis C, Manaenko A, Zhang J. Hydrocephalus after subarachnoid hemorrhage: Pathophysiology, diagnosis, and treatment. Biomed Res Int 2017;2017:8584753.

28. Frontera JA, Claassen J, Schmidt JM, Wartenberg KE, Temes R,
Connolly ES Jr., et al. Prediction of symptomatic vasospasm after subarachnoid hemorrhage: The modified fisher scale. Neurosurgery 2006;59:21-7.

29. Ogilvy CS, Carter BS. A proposed comprehensive grading system to predict outcome for surgical management of intracranial aneurysms. Neurosurgery 1998;42:959-68; discussion 968-70.

30. Lantigua H, Ortega-Gutierrez S, Schmidt JM, Lee K, Badjatia N, Agarwal S, et al. Subarachnoid hemorrhage: Who dies, and why? Crit Care 2015;19:309.

31. Hoogmoed J, Coert BA, van den Berg R, Roos YB, Horn J, Vandertop WP, et al. Early treatment decisions in poor-grade patients with subarachnoid hemorrhage. World Neurosurg 2018;119:e568-73.

32. Helbok R, Kurtz P, Vibbert M, Schmidt MJ, Fernandez L, Lantigua $\mathrm{H}$, et al. Early neurological deterioration after subarachnoid haemorrhage: Risk factors and impact on outcome. J Neurol Neurosurg Psychiatry 2013;84:266-70.

33. Kassell NF, Torner JC, Haley EC Jr., Jane JA, Adams HP, Kongable GL. The international cooperative study on the timing of aneurysm surgery. Part 1: Overall management results. J Neurosurg 1990;73:18-36.

34. Osawa M, Hongo K, Tanaka Y, Nakamura Y, Kitazawa K, Kobayashi S. Results of direct surgery for aneurysmal subarachnoid haemorrhage: Outcome of 2055 patients who underwent direct aneurysm surgery and profile of ruptured intracranial aneurysms. Acta Neurochir (Wien) 2001;143:655-63; discussion 663-4.

35. Erginoğlu U. Intrakranyal Anevrizma Tedavisinde Erken Cerrahi Yaklaşımın Prognoza Etkisi, Istanbul; 2010.

36. Arslan R. İntrakraniyal Anevrizma Tedavisinde Erken Cerrahi Yaklaşımı Tedavi Sonucu Üzerindeki Önemi, İstanbul; 2006. 